\title{
PENGARUH MODEL PEMBELAJARAN KOOPERATIF TIPE STAD TERHADAP HASIL BELAJAR FISIKA SISWA PADA MATERI FLUIDA DI KELAS XI IPA SMA NEGERI 1 PADANGSIDIMPUAN
}

\author{
Rini Anggraini Pakpahan \\ Fakultas Keguruan dan Ilmu Pendidikan, Universitas Graha Nusantara \\ e-mail: rini_aini35@yahoo.com
}

\begin{abstract}
This research aimed to determine the effect of STAD cooperative learning model to student learning outcomes in the subject matter of fluid at class XI IPA SMA Negeri 1 Padangsidimpuan. This was experimental research with One Group Pretest Posttest Design. The population was all class XI IPA SMA Negeri 1 Padangsidimpuan (128 students) and sample was taken through cluster random sampling, so the sample was 32 students. The instrument of this research was the achievement test. The result of this study indicated that student learning outcomes using STAD cooperative learning model $(74,69)$ were higher than student learning outcomes using convensional learning model $(62,25)$. Based on the result of hypothesis testing at significance level $5 \%$ with degree of freedom $31, t_{\text {count }}=9,79>t_{\text {table }}=$ 1,698 then the hypothesis can be accepted, it means that there was influence STAD cooperative learning model to student learning outcomes in the subject matter of fluid at class XI IPA SMA Negeri 1 Padangsidimpuan.
\end{abstract}

Keywords: STAD learning model, student learning outcomes

\begin{abstract}
Abstrak
Penelitian ini bertujuan untuk mengetahui pengaruh model pembelajaran kooperatif tipe STAD (Student Teams Achievement Division) terhadap hasil belajar siswa pada materi pokok Fluida di kelas XI IPA SMA Negeri 1 Padangsidimpuan. Jenis penelitian ini adalah eksperimen yang didesain dalam model One Group Pretest Posttest Design. Populasi dalam penelitian ini adalah seluruh siswa kelas XI IPA SMA Negeri 1 Padangsidimpuan yang terdiri dari 4 kelas (128 siswa). Sampel penelitian ini ditentukan dengan cara cluster random sampling yaitu berjumlah 32 orang. Instrumen penelitian ini adalah tes hasil belajar. Hasil penelitian menunjukkan hasil belajar siswa menggunakan model pembelajaran kooperatif tipe STAD belajar siswa lebih tinggi $(74,69)$ dibandingkan hasil belajar siswa menggunakan model pembelajaran konvensional $(62,25)$. Berdasarkan hasil uji hipotesis pada taraf signifikansi 5\% dengan dk = 31 , diperoleh $t_{\text {hitung }}=9,79>t_{\text {tabel }}=1,698$ maka hipotesis yang diajukan diterima, artinya terdapat pengaruh model pembelajaran kooperatif tipe STAD (Student Teams Achievement Division) terhadap hasil belajar Fisika materi pokok Fluida di kelas XI IPA SMA Negeri 1 Padangsidimpuan.
\end{abstract}

Kata Kunci: model pembelajaran kooperatif tipe STAD, hasil belajar siswa

\section{PENDAHULUAN}

Pendidikan adalah salah satu upaya untuk mencerdaskan kehidupan bangsa dan untuk meningkatkan kualitas sumber daya manusia (SDM). Guru memiliki peranan penting dalam 
peningkatan daya saing sumber daya manusia dan dalam menentukan kualitas pengajaran yang dilaksanakan. Dalam melaksanakan kegiatan pembelajaran para guru tidak hanya harus menguasai bahan, tetapi guru juga harus mengetahui bagaimana cara menyampaikan materi pelajaran dan memahami karakteristik para siswa yang menerima pelajaran tersebut.

Ilmu Pengetahuan Alam (IPA) merupakan hasil kegiatan manusia berupa gagasan dan konsep yang terorganisasi tentang alam sekitar, yang diperoleh dari serangkaian proses ilmiah. Fisika adalah bagian dari mata pelajaran Ilmu Pengetahuan Alam yang pada dasarnya menarik untuk dipelajari karena di dalamnya dapat dipelajari gejala-gejala atau fenomena yang terjadi di jagad raya. Dari hasil observasi di beberapa sekolah di kota Padangsidimpuan, mata pelajaran fisika masih dianggap siswa pelajaran yang sulit, membosankan dan penerapan rumus-rumus ke dalam soal juga tidak mudah, sehingga menyebabkan kurangnya minat siswa untuk mempelajari fisika. Dari hasil wawancara dengan guru mata pelajaran fisika di SMA Negeri 1 Padangsidimpuan mengatakan bahwa siswa menganggap fisika itu sulit, dan kurangnya minat siswa salah satunya disebabkan oleh guru masih menggunakan model pembelajaran konvensional yang lebih berpusat pada guru sehingga menyebabkan siswa kurang aktif dalam pembelajaran. Di samping itu, penulis juga melakukan wawancara dengan beberapa siswa kelas XI IPA di SMA Negeri 1 Padangsidimpuan yang mengatakan bahwa fisika itu sulit, banyak rumus, dan dalam menyelesaikan soal mereka selalu mencari rumus fisika mana yang cocok untuk menyelesaikan soal tersebut tanpa memahami konsep fisika terlebih dahulu.

Hal ini merupakan sikap negatif yang mengakibatkan dorongan untuk belajar lebih giat menjadi rendah sehingga siswa menjadi pasif dan kurangnya kerjasama antar siswa. Apabila hal ini terus dibiarkan, maka pada akhirnya mutu pendidikan akan semakin rendah dan kualitas sumber daya manusia berkurang. Generasi penerus akan semakin sedikit yang dapat memahami konsep fisika degan benar dan pemanfaatan ilmu fisika dalam kehidupan seharihari juga semakin minim. Hal ini akan menyebabkan terjadinya keterpurukan dalam bidang ilmu pengetahuan dan teknologi.

Model pembelajaran merupakan suatu prosedur yang sistematis dalam mengatur pembelajaran agar tujuan yang diharapkan dapat tercapai dengan baik. Dalam mencapai tujuan pembelajaran, ada berbagai macam model pembelajaran yang dapat digunakan oleh guru. Salah satunya adalah model pembelajaran kooperatif tipe STAD (Student Teams Achievement Division). Tipe ini dikembangkan oleh Slavin yang menekankan pada aktivitas dan interaksi antar siswa sehingga diharapkan dapat mencapai prestasi yang maksimal. Menurut Slavin (2005), STAD merupakan salah satu tipe dari model pembelajaran kooperatif yang paling sederhana di mana siswa dikelompokkan menjadi beberapa kelompok dengan anggota empat sampai lima orang, dan setiap kelompok harus heterogen.

Model pembelajaran kooperatif tipe STAD terdiri dari enam langkah atau fase. Ibrahim dalam Trianto (2010) menyatakan langkah-langkah pembelajaran yaitu (1) menyampaikan tujuan dan memotivasi siswa, (2) menyajikan/menyampaikan informasi, (3) mengorganisasikan siswa dalam kelompok-kelompok belajar, (4) membimbing kelompok bekerja dan belajar, (5) evaluasi, (6) memberikan penghargaan. pada tahap ini guru memberikan penghargaan kepada kelompok berdasarkan skor rata-rata yang diperoleh tim. Apabila semua kelompok memperoleh hasil belajar yang sempurna, maka semua kelompok diberi penghargaan. Beberapa penelitian yang membahas tentang model pembelajaran kooperatif tipe STAD antara lain Wardana, dkk (2017), Asneli Lubis (2012), dan Ernawita, dkk (2018).

Dalam STAD skor rata-rata tim didasarkan pada jumlah poin kemajuan yang diperoleh masing-masing siswa dalam kelompok. Poin kemajuan ini ditentukan berdasarkan skor yang diperoleh siswa pada tes awal. Untuk menghitung poin kemajuan tersebut dapat dilihat pada tabel berikut. 
Tabel 1

Pedoman Perhitungan Poin Kemajuan Siswa

\begin{tabular}{|c|c|}
\hline Skor Kuis & Poin Kemajuan \\
\hline Lebih dari 10 poin di bawah skor awal & 5 \\
\hline $10-1$ poin di bawah skor awal & 10 \\
\hline Skor awal sampai 10 poin di atas skor awal & 20 \\
\hline Lebih dari 10 poin di atas skor awal & 30 \\
\hline Kertas jawaban sempurna (terlepas dari skor awal) & 30 \\
\hline
\end{tabular}

Slavin dalam Isjoni (2010)

Berikut ini adalah kriteria predikat atau penghargaan sesuai dengan perolehan skor yang diperoleh masing-masing kelompok.

Tabel 2

Perolehan Skor dan Penghargaan Tim Tipe STAD

\begin{tabular}{|c|c|c|}
\hline No. & Perolehan Skor & Predikat \\
\hline 1 & $15-19$ & Good Team \\
2 & $20-24$ & Great Team \\
3 & $25-30$ & Super Team \\
\hline
\end{tabular}

Yatim Rianto (2010)

Model pembelajaran kooperatif tipe STAD diharapkan dapat meningkatkan minat siswa untuk belajar fisika dan dapat meningkatkan kerjasama di antara para siswa sehingga siswa lebih aktif dalam pembelajaran. Persepsi siswa yang awalnya menganggap "fisika itu sulit” akan berubah menjadi "fisika itu santai dan mengasyikkan”. Dengan demikian, penelitian ini membahas tentang Pengaruh Model Pembelajaran Kooperatif Tipe STAD Terhadap Hasil Belajar Fisika Siswa Pada Materi Fluida Di Kelas XI IPA SMA Negeri 1 Padangsidimpuan.

\section{METODE PENELITIAN}

Adapun metode yang digunakan adalah metode deskriptif dan metode eksperimen. Metode deskriptif digunakan untuk melihat gambaran tentang kedua variabel. Sedangkan metode eksperimen digunakan untuk melihat pengaruh di antara kedua variabel penelitian. Populasi merupakan keseluruhan objek penelitian. Adapun yang menjadi populasi dalam penelitian adalah semua siswa kelas XI IPA SMA Negeri 1 Padangsidimpuan yang terbagi dalam 4 kelas dengan jumlah siswa 128 orang. Sampel adalah bagian dari yang mewakili sebagian dari populasi. Teknik pengambilan sampel yang digunakan adalah cluster random sampling dimana setiap kelas memiliki kesempatan yang sama untuk menjadi sampel penelitian. Adapun sampel yang diambil adalah kelas XI IPA 3 berjumlah 32 siswa.

Penelitian ini didesain dalam model one group pretest posttest design dengan melaksanakan eksperimen hanya pada satu kelas saja tanpa ada kelas pembanding. Hal ini sesuai dengan yang dinyatakan oleh Suharsimi Arikunto (2010) bahwa one group pretest posttest design yaitu eksperimen yang dilaksanakan pada satu kelompok saja tanpa kelompok pembanding. Kelas sampel diberikan pretest yang bertujuan untuk melihat kemampuan awal siswa. Setelah dikenai perlakuan menggunakan model pembelajaran kooperatif tipe STAD dalam pembelajaran, kelas sampel diberikan posttest untuk melihat kemampuan akhir yang dimiliki siswa.

Selanjutnya hipotesis yang diajukan dibuktikan dengan menggunakan uji "t” (“t” test). Rumus uji “t” yang digunakan adalah: 
Keterangan:

$$
\mathrm{t}=\frac{\overline{\mathrm{D}}}{\sqrt{\frac{\sum \mathrm{D}^{2}-\frac{\left(\sum \mathrm{D}\right)^{2}}{\mathrm{~N}}}{\mathrm{~N}(\mathrm{~N}-1)}}}
$$

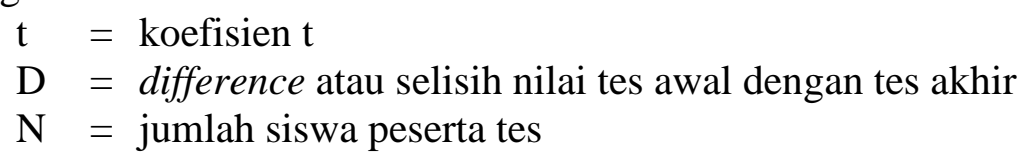

\section{HASIL DAN PEMBAHASAN}

Berdasarkan hasil penelitian yang dilakukan terhadap variabel Y diperoleh data yaitu hasil belajar fisika siswa sebelum penggunaan model pembelajaran kooperatif tipe STAD diperoleh nilai rata-rata (mean) 62,08, nilai tengah (median) 60,33 dan modus 66,67. Sedangkan nilai terendah adalah 40,00 dan nilai tertinggi adalah 86,67. Nilai rata-rata 62,08 termasuk dalam kategori cukup, yang menunjukkan bahwa hasil belajar fisika siswa perlu ditingkatkan dan solusi yang diambil adalah dengan menggunakan model pembelajaran kooperatif tipe STAD dalam pembelajaran.

Hasil belajar fisika siswa setelah penggunaan model pembelajaran kooperatif tipe STAD diperoleh nilai rata-rata (mean) 73,54, nilai tengah (median) 73,33 dan modus 73,33. Sedangkan nilai terendah yang diperoleh siswa adalah 60,00 dan nilai tertinggi adalah 93,33. Nilai rata-rata 73,54 termasuk dalam kategori baik, yang menunjukkan bahwa hasil belajar fisika siswa pada materi pokok fluida telah mengalami peningkatan setelah menggunakan model pembelajaran kooperatif tipe STAD dalam pembelajaran.

Pengujian hipotesis dilakukan untuk mengetahui ada tidaknya pengaruh antara kedua variabel yang diteliti dan untuk mengetahui apakah hipotesis tersebut dapat diterima atau ditolak. Untuk memperoleh angka indeks " $t$ " test dari sampel penelitian, ada beberapa tahap pelaksanaan perhitungan yang harus dilakukan yaitu uji normalitas dan uji homogenitas.

1. Melakukan uji normalitas data

Uji normalitas dilakukan untuk mengetahui apakah data yang diperoleh dalam penelitian ini berdistribusi normal atau tidak. Untuk itu penulis mengambil tipe pengajuan dengan chi kuadrat dengan asumsi apabila $x^{2}$ hitung $<x^{2}$ tabel maka data berdistribusi normal.

Berdasarkan data hasil belajar Fisika siswa pada materi Fluida sebelum penggunaan model pembelajaran kooperatif tipe STAD diperoleh nilai rata-rata 62,25 dan simpangan baku 12,95. Berdasarkan perhitungan, diperoleh $x^{2}$ hitung $=3,8571$. Dari tabel kritik chi kuadrat diketahui bahwa dengan $\mathrm{db}=6-1=5$, harga $x^{2}$ dalam interval kepercayaan $95 \%$ adalah 11,1. Berarti $x^{2}$ hitung $<x^{2}$ tabel, maka data berada dalam sebaran normal. Selanjutnya dari data hasil belajar Fisika siswa pada materi fluida setelah penggunaan model pembelajaran kooperatif tipe STAD diperoleh nilai rata-rata 74,69 dan simpangan baku 8,13. Berdasarkan perhitungan, diperoleh $x^{2}$ hitung $=1,5924$. Dari tabel kritik chi kuadrat diketahui bahwa dengan $\mathrm{db}=6-1=$ 5, harga $x^{2}$ dalam interval kepercayaan $95 \%$ adalah 11,1. Berarti $x^{2}$ hitung $<x^{2}$ tabel, maka data berada dalam sebaran normal.

\section{Melakukan uji homogenitas}

Uji homogenitas dilakukan untuk mengetahui apakah sampel yang diambil dari populasi mempunyai kondisi yang sama ketika perlakuan (hasil belajar Fisika materi pokok mekanika fluida sesudah penggunaan model pembelajaran kooperatif tipe STAD dan hasil belajar Fisika materi pokok mekanika fluida sebelum penggunaan model pembelajaran kooperatif tipe STAD). Adapun uji homogenitas yang digunakan adalah uji F. Harga varians untuk posttest adalah 8,13. Sedangkan harga varians untuk pretest adalah 12,95. Harga $\mathrm{F}_{\text {hitung }}$ diperoleh $F_{\text {hitung }}$ sebesar 1,59. Harga $F_{\text {hitung }}$ tersebut dikonsultasikan dengan $F_{\text {tabel }}$ pada taraf 
signifikan $5 \%$ diperoleh $\mathrm{F}_{\text {hitung }}$ sebesar 1,59 lebih kecil dari $\mathrm{F}_{\text {tabel }}=3$ 3,28. Hal ini berarti bahwa sampel penelitian mempunyai varians yang homogen.

Hipotesis yang diajukan dalam penelitian ini diujikan melalui uji “t”. Dari perhitungan yang dilakukan diperoleh nilai thitung 9,79 dan ttabel pada taraf kepercayaan 95\% dengan derajat kebebasan $(\mathrm{dk})=\mathrm{N}-1=32-1=31$ adalah 1,698 maka thitung lebih besar dari tabel $(9,79>$ 1,698). Hal ini menunjukkan bahwa hipotesis diterima.

\section{SIMPULAN}

Berdasarkan hasil penelitian yang dilakukan, penulis menarik beberapa kesimpulan yang didasarkan pada hasil pengumpulan data. Adapun kesimpulan tersebut sebagai berikut :

1. Nilai rata-rata hasil belajar Fisika siswa sebelum menggunakan model pembelajaran kooperatif tipe STAD pada materi pokok fluida di kelas XI IPA SMA Negeri 1 Padangsidimpuan adalah 62,25 termasuk dalam kategori “cukup”.

2. Nilai rata-rata hasil belajar Fisika siswa setelah menggunakan model pembelajaran kooperatif tipe STAD pada materi pokok fluida di kelas XI IPA SMA Negeri 1 Padangsidimpuan adalah 74,69 termasuk dalam kategori "baik".

3. Terdapat pengaruh yang signifikan antara model pembelajaran kooperatif tipe STAD terhadap hasil belajar siswa pada materi pokok fluida di kelas XI IPA SMA Negeri 1 Padangsidimpuan.

\section{DAFTAR PUSTAKA}

Arikunto, Suharsimi. 2010. Manajemen Penelitian. Jakarta: Rineka Cipta.

Ernawita dan Saitri, Rini. 2018. Pengaruh Model Pembelajaran Kooperatif Tipe Student Teams Achievement Division Terhadap Motivasi Belajar Peserta Didik Di SMAN 8 Banda Aceh. Jurnal Pendidikan Sains Indonesia, Vol. 6, No. 1.

Isjoni. 2010. Cooperative Learning Efektivitas Pembelajaran Kelompok. Bandung: Alfabeta.

Lubis, Asneli. 2012. Pengaruh Model Pembelajaran Kooperatif Tipe STAD Terhadap Hasil Belajar Fisika Pada Materi Pokok Gerak Lurus Siswa Di Kelas X SMA Swasta UISU Medan. Jurnal Pendidikan Fisika, Vol. 1 No. 1, 9-16.

Rianto, Yatim. 2010. Paradigma Baru Pembelajaran. Jakarta: Kencana.

Slavin, Robert E. 2005. Cooperative Learning: Teori, Riset dan Praktik, Terjemahan Narulita Yusron. Bandung: Nusa Media.

Trianto. 2010. Mendesain Model Pembelajaran Inovatif-Progresif: Konsep, Landasan, dan Implementasinya pada KTSP. Jakarta: Kencana.

Wardana, Ika, Banggali, Tinggi, dan Husain, Halimah. 2017. Penerapan Model Pembelajaran Kooperatif Tipe STAD (Student Teams Achievement Division) untuk Meningkatkan Hasil Belajar Siswa Kelas XI IPA Avogadro SMA Negeri 2 Pangkajene (Studi Pada Materi Asam Basa). Jurnal Chemica, Vol. 18, No. 1, 76-84.

Wena, Made. 2009. Strategi Pembelajaran Inovatif Kontemporer: Suatu Tinjauan Konseptual Operasional. Jakarta: Bumi Aksara. 